\title{
Analisis Struktur Pertunjukan Opera Batak Sisingamangaraja XII: Episode Tongtang I Tano Batak
}

\author{
Sulaiman, Rosta Minawati, Enrico Alamo, Sherli Novalinda \\ Program Studi Teater, Program Studi Televisi dan Film, dan Program Studi Seni Tari \\ Fakultas Seni Pertunjukan dan Fakultas Seni Rupa dan Desain, \\ Institut Seni Indonesia Padang Panjang \\ Jalan Bahder Johan Padang Panjang, Sumatera Barat 27128 \\ Email: sulaimanjuned@gmail.com; rostaminawati@yahoo.co.id; \\ godottwo@gmail.com; sherlinovalinda@gmail.com
}

\begin{abstract}
Opera Batak is a traditional performance genre from the Toba Batak ethnic group. Opera Batak is staged based on oral tradition through acting, music, and dance. The creation of artistic works aims to preserve Sisingamangaraja XII's historical values. The research for the artwork started with observation, interviews, and literature studies; while steps for creating artwork were the search phase for ideas, the stage of giving content, the development stage, and the finalization stage. Transitions of performers and sections of the drama are accompanied by musical instruments including gondang, suling, serunai, kecapi, hesek, odap, and garantung. This mixture is intended to bring the drama to life and to entertain the audience. The figures in Opera Batak are Sisingamangaraja XII, Patuan Anggi, Putri Lopian, Boru Sagala, Somaling, Panglima Sarbut and Panglima Amandopang. This episode tells how the war against the Dutch company in the Batak land for about 30 years. It was arranged with a plot, dramatic, and tight conflicts to show Sisingamangaraja's humanity and his familyhood during the war.
\end{abstract}

Keywords: Opera Batak Theater, Sisingamangaraja XII, Tongtang I Tano Batak

\begin{abstract}
ABSTRAK
Opera Batak merupakan seni pertunjukan tradisi dalam masyarakat Batak. Opera Batak ditampilkan melalui sastra lisan, pemeranan, musik, dan tarian. Penciptaan karya bertujuan untuk melestarikan nilai-nilai kesejarahan Sisingamangaraja XII. Metode penciptaan dilakukan dengan diawali riset melalui observasi, wawancara, dan studi pustaka, dengan langkah garap: tahap pencarian, tahap memberi isi, tahap pengembangan, dan tahap pemantapan. Opera Batak dipandu pencerita dalam mengenalkan tema, menyapa penonton, menggambarkan kisah, dan menggenalkan pemain. Peralihan pemain dan bagian cerita diiringi musik yang terdiri atas: gondang, suling, serunai, kecapi, hesek, odap, dan garantung. Tokoh Opera Batak dalam episode Tongtang I Tano Batak adalah Sisingamangaraja XII, Patuan Anggi, Putri Lopian, Boru Sagala, Somaling, Panglima Sarbut, dan Panglima Amandopang. Episode ini menceritakan bagaimana perperangan melawan kompeni Belanda di tanah Batak yang kurang lebih 30 tahun lamanya. Drama ini disusun dengan alur, dramatik, dan konflik yang rapat untuk memperlihatkan sisi kemanusiaan dan sifat kekeluargaan Sisingamangaraja dalam menghadapi perperangan.
\end{abstract}

Kata kunci: Opera Batak, Teater, Sisingamangaraja XII, Tongtang I Tano Batak 


\section{PENDAHULUAN}

Opera Batak adalah salah satu kesenian yang eksistensinya sudah semakin menghilang. Kalaupun terjadi pementasan terlihat hanya dilakukan oleh beberapa kelompok saja. Semaraknya pementasan Opera Batak di masa lalu, lebih disebabkan oleh keadaan masyarakat yang pada saat itu belum terimbas pada kemajuan teknologi informasi. Presiden Sukarno mengukuhkan nama Opera Seni Ragam Indonesia disingkat menjadi Opera Batak Serindo. Serindo berarti Seni Ragam Indonesia. Nama tersebut adalah pemberian dari Presiden Soekarno. Pada tahun 1956, Opera Batak Tilhang Serindo resmi dengan Akte Notaris Renatus Lumban Raja tertanggal Pematang Siantar 2 April 1956 No. 1 (Purba, 2002: 40).

Perkembangan kesenian Opera dirintis pertama kali oleh Tilhang Oberlin Gultom pada tahun 1920 dengan mendirikan kelompok kesenian yang dijuluki Tilhang Parhasapi. Kelompok ini merupakan cikal dari keberadaan Opera Batak. Tilhang dan kelompoknya yang hanya beranggotakan 3 (tiga) orang memang layak disebut sebagai pelopor pertunjukan yang sungguh-sungguh dibutuhkan oleh masyarakat, yang misi utama Tilhang saat itu adalah membakar semangat untuk mempertahankan haknya dari penjajahan (Belanda). Dalam hal ini, Purba (2002: 28) menjelaskan:

Awal abad XX, kondisi kesenian yang hanya dilibatkan dalam upacara serta kondisi masyarakat yang ditekan oleh penjajah, seorang seniman bernama Tilhang Oberlin Gultom mencetuskan gagasan untuk mendirikan kesenian yang ditampilkan diluar upacara.

Merujuk penjelasan tersebut, opera tidaklah berjalan mulus. Berbagai upaya dilakukan penjajah untuk menghalangi pertunjukan opera dengan cara melarangnya atau mengijinkan berlangsungnya pertunjukan, tetapi dengan persyaratan pajak yang amat tinggi. Akan tetapi, dengan tekad kesenimanan yang tinggi, Tilhang pun tak hen- ti-henti berusaha untuk mempertahankan opera, misalnya dengan mengganti nama. Selanjutnya, pada tahun 1928 untuk menarik perhatian masyarakat, kesenian Tilhang Parhasapi berganti nama menjadi Opera Batak. Pertunjukan ini telah dilengkapi dengan berbagai unsur seni di dalamnya, yakni menjadi pertunjukan mengandung unsur musik, lagu tari, dan cerita (Siahaan, 1976/1977: 15).

Sejak itu, Opera Batak yang lain pun mulai bermunculan. Nama opera bukan lagi nama baru dan menjadi dekat di telinga masyarakat. Materi cerita yang ditampilkan dalam opera adalah sesuatu yang sangat dekat dengan kehidupan masyarakat, yakni sendi-sendi kehidupan masyarakat itu sendiri. Adapun materi ceritanya ada yang berupa kisah nyata, legenda, dan ada juga kiasan atau perumpamaan yang dihadirkan sekiranya masih relevan dengan problema kehidupan masyarakat.

Beberapa pemikir Batak sebenarnya telah melakukan upaya revitalisasi opera dengan satu pertimbangan bahwa opera turut ambil bagian untuk membangun manusia seutuhnya serta membentuk kehalusan rasa yang berbudi pekerti. Pada pertengahan tahun 2002 proyek revitalisasi Opera Batak yang diinisiasi oleh ATL (Asosiasi Tradisi Lisan) menghasilkan satu grup percontohan bernama grup Opera Silindung. Grup inilah sebagai pemicu untuk membangkitkan Opera Batak sampai 2004, yang kemudian pengembangannya ditangani langsung oleh Thompson HS bersama grupnya PLOt pada tahun 2005 di Pematang Siantar. Target revitalisasi Opera Batak pada awalnya selesai pada tahun 2012. Justru kehadiran manajemen PLOt, membuat Opera Batak tidak lagi sekedar direvitalisasi, tapi juga dimanfaatkan, dimodifikasi dan diperkenalkan lebih luas. Opera Batak menjadi lebih kreatif, termasuk kompromi bahasa untuk memperkenalkan potensi-potensi tradisi ke penonton yang lebih luas. 
Opera Batak Sisingamangaraja XII episode Tongtang I Tano Batak (Pertempuran di Tanah Batak) adalah lakon yang terinspirasi dari kisah kepahlawanan seorang pejuang dari tanah Tapanuli (Bakara) yang mempertahankan Tano Batak dari penjajahan Belanda. Karya Opera Batak Sisingamangaraja XII episode Tongtang I Tano Batak (Peperangan di Tanah Batak) digarap dengan menggunakan konsep teater modern. Misalnya, para pemain melakukan latihan-latihan sebagaimana proses dalam teater modern. Tortor sebagai salah satu gerak tari dalam Opera Batak dikreasikan dengan beberapa karya tari yang mengusung suasana dan peristiwa dalam Opera Batak ini. Opera Batak ini tidak sepenuhnya mengubah apa yang menjadi pakem di dalam Opera Batak. Hal yang prinsip, seperti uning-uningan, tortor pembuka dan tortor penutup, amalopas sebagai pembawa cerita, dan cerita sebagai bagian pesan Opera Batak tetap dipertahankan.

Di sini, Opera Batak Sisingamangaraja XII episode Tongtang I Tano Batak (Peperangan di Tanah Batak) mendapatkan perhatian serius dari penulis, baik dalam pengumpulan bahan-bahan penelitian maupun proses pembuatan karya tulis dan pertunjukan. Hal ini diharapkan dapat menjadi acuan baik dalam tim penelitian maupun kelompok lain.

\section{METODE}

Opera Batak Sisingamangaraja XII episode Tongtang I Tano Batak (Peperangan di Tanah Batak) dikerjakan oleh penulis menjadi satu bentuk pertunjukan Opera Batak dengan menggunakan metode atau cara yang juga dilakukan oleh Suyatna Anirun dalam proses kreatif penyutradaraannya. Metode ini secara umum terbagi dalam empat langkah kreatif yang meliputi: tahap pencarian; tahap memberi isi; tahap pengembangan; dan tahap pemantapan (Anirun, 2002: 123).

a. Tahap Pencarian merupakan rang- kaian tindakan yang menelusuri keterkaitan berbagai sumber penciptaan, yakni antara lakon Sisingamangaraja XII episode Tongtang I Tano Batak (Peperangan di Tanah Batak) yang sudah dibukukan yang berasal dari cerita lisan Sisingamangaraja XII.

b. Tahap Memberi Isi, merupakan rangkaian tindakan untuk mengembangkan aspek-aspek psikomotorik. Pada tahap ini, interpretasi carito sudah harus sedapat mungkin memberikan dorongan kepada pemain dalam mewujudkan lakuan 'verbal' maupun 'nonverbal' berdasarkan desain lakuan yang bersifat umum yang telah ditemukan dalam interpretasi lakon.

c. Tahap Pengembangan, merupakan pengulangan-pengulangan terhadap tahapan memberi isi, yakni dengan menempatkan perpindahan gerak, gestur, lakuan dalam lakuan yang sudah terlihat spontan.

d. Tahap Pemantapan, merupakan rangkaian tindakan yang merupakan usaha untuk menampilkan carito secara ensambel dan utuh. Indikator keberhasilan yang digunakan adalah pencapaian harmoni, respon set dekorasi, relevansi iringan, ilustrasi musik dan kesesuaian warna dominan pada set dekorasi dengan penataan lampu.

Secara konkrit, metode penciptaan $c a-$ rito Opera Batak Sisingamangaraja XII episode Tongtang I Tano Batak (Peperangan di Tanah Batak) dapat dilihat dari berbagai bentuk latihan yang secara berurutan dapat dijelaskan sebagai berikut.

1. Pembacaan carito (naskah) merupakan latihan awal dalam perancangan untuk menjajaki penafsiran carito (naskah). Orientasi lain dari kegiatan ini adalah pencarian nada dasar vokal bagi kebutuhan peran. Pusat perhatian kemudian diarahkan pada diksi, intonasi, dan artikulasi vokal. Selain itu, hal ini dapat mengantarkan pada pemahaman lakon.

2. Blocking Kasar, adalah teknik pengaturan langkah-langkah para pemain untuk membentuk pengelompokan dikarenakan 
perubahan suasana dalam carito. Sebelum pencapaian blocking yang baku, maka para pemain melakukan pencarian gestur dan gerak-gerak secara acak dan seringkali masih berubah-ubah.

3. Blocking Halus, merupakan tahapan latihan yang bertitik tolak dari blocking kasar. Seluruh gerak dan gestur pemain yang membentuk block (kelompok), telah menjadi susunan pola lantai yang baku. Pada tahapan ini, latihan lebih diarahkan pada penumbuhan motivasi pada setiap gerakan yang dibuat. Kegiatan konkret yang dilakukan dalam blocking halus ini adalah menyeleksi semua capaian-capaian blocking kasar dengan mengamati blocking dan gerakan dalam adegan demi adegan.

4. Detailisasi, merupakan tahapan pematangan dari blocking halus yang telah dicapai sebelumnya. Pada tahap ini, pemeran sudah harus mampu membangun penghayatan dirinya sehingga setiap gerak dan ucapannya terkesan wajar. Dalam hal ini, penata melakukan penyelarasan akhir terhadap semua komponen artistik yang diperlukan, daya dukung musik terhadap emosi dan suasana kejadian, kontekstualisasi pilihan instrumen terhadap latar carito, dan harmonisasi dengan seni peran yang akan disajikan.

\section{HASIL DAN PEMBAHASAN}

Konsep Opera Batak Sisingamangaraja XII episode Tongtang I Tano Batak (Peperangan di Tanah Batak)

Opera Batak Sisingamangaraja XII episode Tongtang I Tano Batak (Peperangan di Tanah Batak) merupakan lakon opera yang bersumber dari cerita kepahlawanan Sisingamangaraja XII. Nama kecil Sisingamangaraja XII adalah Patuan Bosar, yang kemudian digelari dengan Ompu Pulo Batu. Ia juga dikenal dengan Patuan Bosar Ompu Pulo Batu. Ia naik tahta pada tahun 1876 menggantikan ayahnya Sisingamangaraja XI yang bernama Ompu Sohahuaon. Sisingamangaraja
XII dikenal juga sebagai raja imam. Ia lahir di Bakara, 18 Februari 1845 dan meninggal di Dairi, pada tanggal 17 Juni 1907. Ia dimakamkan di Tarutung Tapanuli Utara, lalu dipindahkan ke Soposurung, Balige pada tahun 1953. Ketika wafat usianya 62 tahun (Putro, 1981; Sangti, 1978).

Penyajian Opera Batak Sisingamangaraja episode Tongtang I Tano Batak tidak dibatasi oleh budaya subdaerah tersebut. Cerita kepahlawanan ini dikembangkan menjadi lakon yang berdiri sendiri tanpa dibatasi oleh sub-sub daerah, sehingga idiom yang ada di luar Batak Toba pun dapat diadopsi dengan pertimbangan masih termasuk rumpun Batak secara umum. Pengadopsian idiom ini didasari oleh pemikiran bahwa masyarakat di luar suku Batak tidak mempersoalkan sub-etnis, namun semua Batak mereka anggap sebagai satu kesatuan. Desain kebutuhan pertunjukan yang dijadikan simbol dari pemaknaan-pemaknaan yang didapat melalui penelitian dan pengolahan ruang. Salah satunya adalah dengan menghadirkan simbol domestik melalui ulos.

Adapun simbol bangunan/setting yang berdiri di latar belakang panggung dengan masing-masing kain/ulos wakil turut dimunculkan. Material benda yang dominan adalah kayu dan kain. Pemilihan bahan tersebut dilakukan untuk mempermudah pembuatan topeng teater Gundala-gundala. Hal ini diwujudkan untuk mempertimbangkan efek dan kekuatan benda tersebut pada setiap adegan.

Setting serta property dalam Opera Batak Sisingamangaraja tidak sekedar berfungsi sebagai dekoratif namun juga bergerak mengisi ruang pertunjukan. Tiga bagian penting dari setting adalah istano di Bakkara tempat tinggal Sisingamangaraja, hutan dan tempat perperangan, istano merupakan tempat tinggal Sisingamangaraja, perlambang kebahagiaan sekaligus perlambang kesedihan. Hutan merupakan daerah lin- 
tasan yang digunakan untuk mempertegas perjalanan Sisingamangaraja saat bergerilya melawan Belanda.

Unsur cahaya dalam pertunjukan Opera Batak Sisingamangaraja merupakan elemen yang memberikan berbagai fokus pemaknaan. Melalui perhitungan yang tepat, jenis-jenis lampu yang digunakan pada pertunjukan Opera Batak Sisingamangaraja antara lain: lampu freshnel, lampu plano conpeks, dan lampu ellipsoidal. Lampu freshnel digunakan sebagai penerang pada beberapa adegan yang tidak memerlukan fokus tertentu. Lampu plano conpeks digunakan untuk memberi fokus pada beberapa adegan. Lampu ellipsoidal digunakan untuk mempertajam suasana dan efek-efek simbolis pada tokoh maupun setting. Sementara itu, filter warna yang digunakan adalah green, blue, yellow, violet dan netral.

Penataan rias pentas juga merupakan pendukung pemeranan dalam pementasaan lakon. Tata rias dibuat untuk mendukung karakter tokoh sesuai dengan tuntutan cerita pada naskah. Tata rias yang digunakan adalah rias bangsa, rias usia, rias tokoh, rias temporal, rias aksen, dan rias lokal. Tata rias juga berfungsi untuk menonjolkan watak peran yang dimainkan. Tata rias pada umumnya bertujuan untuk mengubah penampilan wajah dengan sempurna sesuai dengan karakter peran. Hal tersebut sama halnya dengan pertunjukan seni tradisi lainnya, seperti yang dimaksudkan Wikandia bahwa tata rias dan busana seni tradisi masih sederhana, yakni menggunakan tata rias dan busana tradisi yang ada (2016: 64).

Rias Opera Batak Sisingamangaraja menunjukan identitas psikologi, yakni rias berfungsi sebagai penegas karakter dari setiap aktor dan aktris. Alat yang digunakan adalah pensil alis hitam untuk mempertegas lingkar mata, eye shadow warna merah dan coklat tua sebagai warna penegas karakter di wilayah atas mata juga pelipis dan lipstik warna merah gelap sebagai pelengkap guratan bibir. Riasan wajah tersebut merupakan penegasan karakter masing-masing tokoh.

Sementara itu, tata aristik merupakan penampakan secara visual yang dibuat oleh tim tata artistik dengan maksud membantu mengkomunikasikan cerita/pesan kepada penonton. Ruang tata artistik teater disesuaikan dengan artistik pentas/panggung yang menjadi latar tempat memainkan lakon. Set yang dirancang oleh penata artistik dengan menginventaris ruang yang dilalui gerak laku, arah pandangan penonton, dan simbol-simbol properti yang digunakan dalam mendukung artistik. Beberapa hal yang dipertimbangkan dalam penataan artistik adalah lokasi, ekspresi, atraktif, kejelasan, kesederhanaan, kemanfaatan, kepraktisan, dan organis.

Tata busana yang dipergunakan adalah berbagai varian ulos. Ulos merupakan sarana pendukung kebudayaan yang dapat digunakan sebagai busana, selendang, selimut, dan kain gendongan (Tambunan, 1977: 186). Ulos digunakan oleh masyarakat Batak untuk memenuhi kebutuhan sehari-hari dan kebutuhan adat tradisi (Basyral dan Hotman, 1987: 21). Ulos yang digunakan dalam perancangan pementasan ini adalah ulos ragi hotang (ulos corak rotan) mengandung arti kekuatan dan keuletan, ulos ragidup (corak hidup), ulos ini sarat dengan nilai kehidupan dan digunakan dalam adat perkawinan Sisingamangaraja XII.

Adapun pemakaian ulos pada pertunjukan bervariasi, ada yang diletakkan di atas kepala, di bawah dan dikenakan sebagai baju. Laki-laki menggunakan ulos di bagian atasnya disebut bande-bande, di bagian bawah disebut singkot, dan penutup kepala disebut tali-tali. Sedangkan pada perempuan, penggunaan ulos di bagian bawah hingga batas dada disebut baen, penutup punggung disebut boba-boba, dan bila digunakan sebagai selendang disebut ampe-ampe, serta sebagai penutup kepala disebut soong. 
Pertunjukan Opera Batak Sisingamangaraja XII tidak hanya didukung oleh tata panggung, tata busana, tata cahaya, tata rias, akan tetapi didukung juga oleh tata suara dan musik. Musik yang digunakan adalah musik Batak Toba. Tata musik untuk mengiringi pementasaan ini bermanfaat untuk memberikan penekanan pada suasana pemain dan untuk mengisi jeda selama pergantian babak atau adegan. Kemudian, tata suara untuk pengaturan suara yang dihasilkan dan dikeluarkan dari berbagai sumber bunyi, seperti suara aktor dan musik.

\section{Musik}

Musik Bagian 1. Opening merupakan musik pengantar pertunjukan Opera Batak Sisingamangaraja episode Tongtang I Tano Batak. Di sini, yang ditampilkan adalah ensambel taganing yang dipadukan dengan sarune bolon, hesek dan hasapi yang terdiri dari instrumen pembawa melodi; sarune bolon/godang (shawn), dan taganing (drum chime). Instrumen ritme variabel mencakup: gordang (single head drum), odap (double head drum), dan taganing. Sedangkan, instrumen ritme konstan mencakup ogung (gong), yang terdiri dari ogung oloan, ihutan, doal, dan panggora; hesek (plat logam atau botol kosong/ struck idiophone). Ensambel gondang hasapi terdiri dari instrumen pembawa melodi, yaitu hasapi (kecapi bersonar dua), sarune etek (serunai kecil), sulim (seruling), garantung (sejenis kulintang). Instrumen ritme variabel mencakup taganing. Instrumen ritme konstan adalah hesek. Fungsi dan kegunaan kedua ensambel ini pada dasarnya sama, yakni bahwa semua gondang atau lagu yang dimainkan dalam ensambel gondang sabangunan adalah juga yang dimainkan oleh gondang hasapi.

Pada musik bagian 1 dihadirkan gondang mula-mula dan tortor dengan (7) tujuh orang penari. Musik terdiri atas ensambel gondang sabangunan.

Musik Bagian 2. Pengantar cerita yang menyanyikan lagu tentang Sisingamanga-
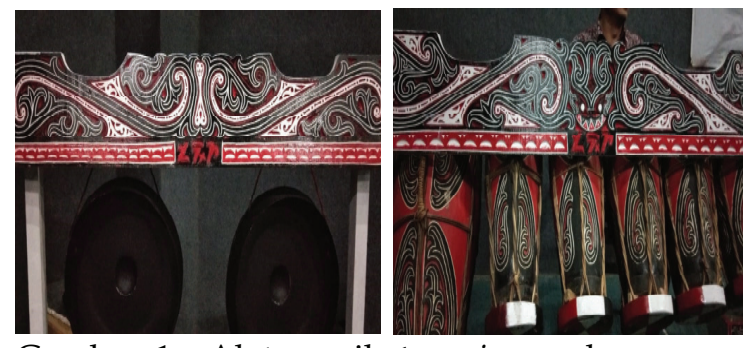

Gambar 1. Alat musik taganing pada pementasan Opera Batak (Dok. Enrico Alamo, 2018)

raja XII menceritakan petuah-petuah serta penghormatan yang dibawakan oleh $\mathrm{Pa}$ rende. Syair lagu ciptaan Nahum Situmorang seperti di bawah ini.

Salenggam ho bombom bombom ni ala huranda (kayu bulat bertumpuk bersitimpa)

Marseakseak manuk da marhorunghorung simata

(ayam mengais berkalung manik-manik simata)

Disido da Ompunta Sisingamangaraja (di situlah Raja kita Sisingamangaraja)

Nahundul di ampuan namalo marhata-hata (bertahta di tempat tenang yang bijak beramanah)

Ansideng ansidoding boto ue $2 \mathrm{X}$ (buaian nyanyi hai dinda)

Ho Inang amangoi amang pargaulan $2 \mathrm{X}$ (betapa seakrab ibu dan ayah)

Tumbatumba si silo simargoligoli da mamahai da antahasa

(timbang-beras berkilauan dudukan perahu jadi tempatnya)

Siantar - Balige Siantar - Balige

(Siantar - Balige Siantar - Balige \{sekarang nama dua kota\} yang terlihat jelas seperti mahligai)

Nangetma da sinise situan doli da unang dibege amanta

(perlahan tegur sang jaka tanpa terdengar sang ayah)

Nadi jabui nadi jabui

(yang sedang di dalam rumah)

Tampollongma disi Tampollongma dison (bunyikan tampollong (onomatope) di situ kubunyikan juga di sini)

Tarehon gajutmi asa hudabu gambir on 
(taruhkan sumpitmu biar kuberikan peramu sirih)

(Sumber Lagu: "Ahu Sisingamangaraja" Prof. Dr. W.B. Sijabat, Sinar Harapan 1982: 16. Terjemahan: Thompson Hs)

Ditinjau dari teksnya, lirik lagu pada Opera Batak mengeskpresikan rasa kasih sayang. Pada berbagai literatur ditemui, seperti pada tulisan Ruswandi bahwa liriklirik lagu karya Mang Koko diciptakan dalam rangka curahan perasaan kasih sayang seorang ibu terhadap anaknya dengan segala kelembutan dan kesabaran lewat kata dan nada (2016: 105-106).

Musik Bagian 3. Ilustrasi video mapping dan musik pengiring gerak tari para prajurit menyusun gerakan sebagai persiapan perlawanan. Pada bagian ini taganing dominan sekali, sementara ogung hanya membuat ketukan pengatur tempo dan irama.

Musik Bagian 4. Musik digarap untuk menghidupkan suasana gerak tari prajurit yang sedang berlatih dan untuk bertempur mengggunakan instrumen taganing dan hesek.

Musik Bagian 5. Pada bagian ini tetabuhan gondang diiringi oleh vokal dengan nyanyian semangat perjuangan. Iringan vokal pria sahut menyahut dalam bahasa Batak. Mars perjuangan dibantu efek musik tekno.

Musik Bagian 6. Bagian ini lebih banyak menggunakan efek musik yang dihadirkan musik tekno, dan suara tembakan, dan meriam saling bergantian. Musik untuk memperkuat suasana Sisingamangaraja mencabut Piso Gaja Dompak.

Musik Bagian 7. Musik ini memberikan ilustrsi bagi penekan suasana dan efek-efek senjata dalam keadaan peretempuran.

Musik Bagian 8. Musik penutup menghadirkan kembali musik tortor dan gondang mula-mula.

\section{Koreografi Gerak: Tortor}

Tortor dalam masyarakat Batak merupakan tarian seremonial yang disajikan dengan iringan musik gondang di kalangan keluarga suhut (tuan rumah). Walaupun
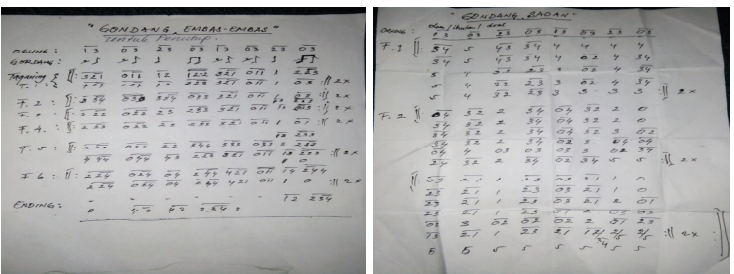

Gambar 2. Notasi musik pada pementasan Opera Batak (Dok. Enrico Alamo, 2018)

tortor merupakan tarian, namun gerakangerakannya menunjukkan bahwa tortor adalah sebuah media komunikasi. Gerakan yang disajikan mengandung interaksi antar-partisipan. Setiap selesai satu permintaan selalu diselingi dengan pukulan gondang dengan ritme tertentu untuk beberapa saat. Setelah permintaan dilaksanakan dengan baik, keluarga suhut yang telah siap $M a-$ nortor (tari-tarian adat Batak) mengatur susunan tempat berdirinya. Dalam interaksi ini juga ada jenis permintaan lagu yang dibunyikan kepada Dewa dan pada roh-roh leluhur agar keluarga suhut (yang mengadakan acara) diberi keselamatan kesejahteraan, kebahagiaan, dan rezeki yang berlimpah ruah, dan upacara adat yang akan dilaksanakan menjadi sumber berkat bagi suhut dan seluruh keluarga, dan para undangan. Tortor dan musik gondang tidak bisa dipisahkan. Keduanya saling memiliki keterkaitan. Tortor dalam Opera Batak Sisingamangaraja ini di samping sebagai pembuka cerita (persembahan) juga merupakan media transisi adegan dan aksentuasi perubahan emosi dan suasana peristiwa yang dibangun dalam cerita. Karenanya, koreografi yang digarap berbentuk tarian yang memiliki konteks dan berbeda-beda dalam setiap bagiannya disesuaikan dengan interpretasi terhadap masing-masing adegan. Koreografi tortor ini tetap berpijak pada kekayaaan gerak dan gestur Batak, serta ragam seni tari tradisional yang berkembang di Sumatera Utara dan hasil eksplorasi gerak yang berangkat dari suasana yang lahir dari cerita. Tortor adalah seni tari dengan menggerakkan seluruh badan de- 
ngan dituntun irama gondang, dengan pusat gerakan pada tangan dan jari, kaki dan telapak kaki, punggung dan bahu. Gondang yang digunakan sebagai alat musik tradisional masyarakat suku Batak Toba adalah gondang sabangunan. "Tortor" berasal dari suara hentakan kaki penari di atas papan rumah adat Batak.

Penari bergerak dengan iringan gondang. Tortor Batak Toba merupakan tarian purba dari tanah Batak yang berasal dari Sumatera Utara, meliputi daerah Tapanuli Utara, Humbang Hasundutan, Toba Samosir, dan Samosir. Gerakan tersebut berupa gerakan kaki (jinjit-jinjit) dan gerakan tangan. Tortor adalah tarian tradisional suku Batak yang ditampilkan dengan iringan musik gondang. Secara fisik, tortor merupakan tarian, namun maknanya terdapat pada setiap gerakan-gerakannya. Hal ini menunjukkan tortor adalah sebuah media komunikasi. Bagian koreografi gerak dalam tarian ini sebagai berikut.

Bagian satu, diawali dengan tortor mula-mula. Bagi masyarakat Batak, semua yang ada di bumi ini pada mulanya ada yang menciptakan (dalam kehidupan masyarakat Batak Toba dikenal dengan Mula Jadi Na Bolon), dan segala sesuatu yang dimulai dengan baik, maka hasilnya akan baik pula. Tarian ini berfungsi untuk membuka cerita sekaligus mengawali pertunjukan Opera Batak Sisingamangaraja. Tortor merupakan gerak tradisi Batak yang ditarikan oleh 7 (tujuh) orang penari.

Bagian dua, tarian pendek untuk mengantarkan pencerita ke atas panggung. Bagian tiga, para prajurit kembali berlatih dan mempersiapkan diri menyambut peperangan. Panglima Sarbut Tampubolon berbincang dengan Patuan Anggi. Mereka membicarakan tentang pengejaran pasukan Belanda dan posisi prajurit Batak yang kian terjepit. Koreografi di sini menginterpretasikan suasana prajurit-prajurit di masa latihan dan mempersiapkan diri untuk pe- rang, serta gambaran mengenai pengejaran pasukan Belanda dan prajurit yang kian terjepit. Suasana tersebut diabstraksikan dengan stimuli gerak dan penerapan dari pengolahan unsur tenaga dan eksplorasi serta fall and recovery.

Bagian empat, menggambarkan ekspresi batin Lopian (anak perempuan Sisingamangaraja XII) ditarikan oleh satu orang penari perempuan, yang mengekspresikan keberanian, kemarahan, kesedihan, dan gejolak dalam jiwa Lopian.

Bagian lima, Sisingamangaraja XII menuju sebuah tempat yang tinggi. Ia berdiri dan memandang semua rakyat yang ada di depannya. Ia mulai mengucapkan salam dengan bahasa Batak lalu berbicara untuk membakar semangat para prajuritnya. Hal itu digambarkan dengan suasana gerak yang mengekspresikan situasi rakyat yang bergegas menunggu rajanya dan gejolak jiwa rakyat dengan berbagai perasaan yang bercampuraduk, berupa harapan, kecemasan, kepercayaan, ketakutan dan semangat yang membara.

Bagian enam, prajurit Sisingamangaraja telah menyingkir ke kampung Pancinoran, di lereng gunung Batu Gaja di wilayah Dairi. Saat itu, Patuan Nagari memberitahu bahwa Patuan Anggi telah tewas. Ia juga melaporkan bahwa panglima perang dan Boru Sagala telah tertangkap. Koreografi pada bagian ini adalah gambaran dari pembunuhan, penangkapan, perang, penyiksaan, dan perlawanan. Eksplorasi gerak dipusatkan pada 3 dasar penggunaan tenaga, yaitu sharing wight, saling mengalirkan tenaga, saling menarik tenaga, control, balance, dan penerapan eksplorasi tenaga bagian tubuh tertentu.

\section{Lakon Cerita}

Penulisan teks lakon Sisingamangaraja XII (Tongtang I Tanah Batak) diawali dari riset, melalui penelusuran berbagai pustaka untuk mendapatkan referensi tentang kisah kesejarahan dan kehidupan Sisingamanga- 
raja XII. Garapan lakon disesuaikan dengan skema adegan dalam mengantarkan cerita Sisingamangaraja. Pada kesempatan ini, kisah yang disampikan sisi kehidupan Sisingamangaraja dan keluarganya dalam menghadapi gejolak batin atas penjajah. Menurut R.M. Pramutomo, dkk (2018: 334), penulisan perlu dilakukan dalam beberapa babak, dan setiap babak terdiri atas beberapa rangkaian adegan. Teks lakon dilengkapi peraga dalang, para pemain, dan musik iringan. Sehubungan dengan pendapat tersebut, Opera Batak juga digarap dengan lakon yang dibagi pada beberapa bagian dan adegan, terdapat pencerita, pemain, musik iringan, dan bahkan, tari. Kombinasi garapan teater modern tersebut terlihat harmonis di atas panggung, apa lagi didukung oleh tata rias dan busana, tata artistik dan kehadiran musik Batak Toba.

Naskah lakon Sisingamangaraja XII dalam Episode Tongtang I Tano Batak yang ditulis oleh Sulaiman Juned dan Edy Suisno, dan disutradarai oleh Enrico Alamo. Pertunjukannya diawali dengan bagian pertama. Yakni, seseorang mengenakan ulos sembari mendendangkan lagu Batak dan bergerak ritmis. Bagian kedua, persiapan gerakan di Lobu Tolu dan adegan Sisingamangaraja melakukan perlawanan, sementara guru Somaling, Pardede dan Panglima Amandopang Manulang memperingatkannya. Bagian ketiga, para prajurit kembali berlatih dan mempersiapkan diri menyambut peperangan, posisi prajurit mulai terjepit oleh Belanda. Bagian keempat, ibunda Boru Sagala sedang menasehati anak gadisnya, Putri Lopian. Boru Sagala berusaha meredam keinginan putrinya berperang di garis depan. Namun, keinginan Putri Lopian tetap teguh untuk bergabung dengan para pejuang di medan perang. Bagian kelima, seorang pencerita yang memakai ulos muncul dengan bersenandung yang menceritakan tentang hidup dan pengorbanan. Bagian keenam, Sisingamangaraja menuju tempat yang tinggi, memandang ke seluruh rakyatnya, lalu membakar semangat untuk tetap bertarung dalam peperangan ini kepada prajuritnya. Bagian ketujuh, Panglima Sarbut Tampubolon dan Panglima Amandopang Manulang membawa pasukannya menyisir hingga Dairi. Mereka berusaha lari dari kejaran Marsose (Kepolisian Belanda zaman Kolonial). Bagian kedelapan, Prajurit Sisingamangaraja XII menyingkir ke kampung Pancinoran di lereng gunung Batu Gaja, Dairi. Patuan Anggi memberitahukan bahwa Patuan Anggi telah tewas, dan beberapa panglima perang serta permaisuri Boru Sagala tertangkap. Putri Lopian juga tewas, Patuan Nagari juga tewas, sementara Sisingamangaraja juga menghembuskan nafas terakhir. Bagian kesembilan, pencerita dengan mengenakan ulos dan memainkan tongkat kembali berceloteh agar dapat mengukur diri terhadap perbuatan. Hal ini menjadi penutup pertunjukan Opera Batak.

Pertunjukan Opera Batak Sisingamangaraja XII dengan garapan teater modern memberikan keterbukaan kreativitas dan inovasi atas pembacaan ulang atas teks sejarah Sisingamangaraja XII. Berpikir kreatif merupakan suatu strategi dalam menghadirkan sesuatu yang baru sesuai dengan zamannya (selera) dan perkembagan sosial budaya masyarakat. Sebagaimana dikatakan To Ngoc Thanh (dalam Minawati dan Nursyirwan, 2018: 349) bahwa kebudayaan tradisional harus dikembangkan untuk memiliki wajah baru bukan hanya menyesuaikan diri, tetapi berkembang dalam kondisi masyarakat sekarang.

4. Penokohan

a. Sisingamangaraja XII

Sisingamangaraja XII adalah pahlawan Nasional dari Tapanuli yang merupakan raja dari turunan sejak Sisingamangaraja I. Kerajaan Sisingamangaraja bersifat spiritual, bukan teritorial. Wilayah spiritual menjadi ranah utama Kerajaan Sisingamanga- 


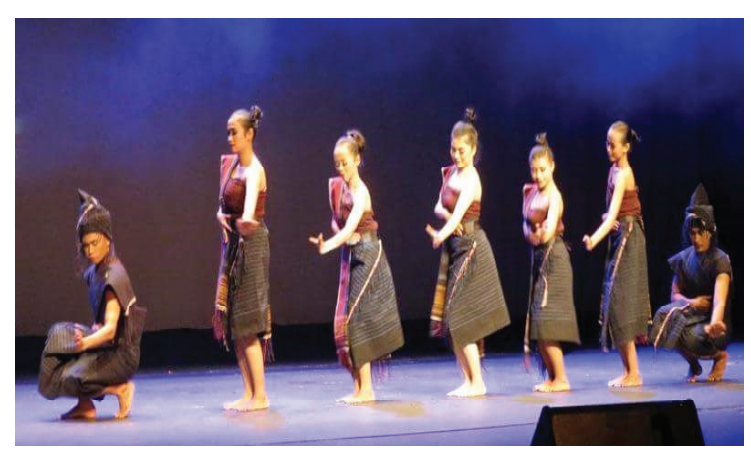

Gambar 3. Tortor Pembuka (mula-mula) Opera Batak Sisingamangaraja di Eksprimental Theatre University Malaya (Dokumen: Enrico Alamo, 2018)

raja di samping beberapa aspek hukum yang tergambar dalam kutipan doa-doa (tonggo) parbaringin (pendeta ritual kuno). Wilayah Kerajaan Sisingamangaraja berpusat di bawah wibawa raja bius Sionom Ompu (6 marga; Purba, Marbun, Bakkara, Sinambela, Manullang, Sihite). Singamangaraja XII memiliki gelar adat: Patuan Bosar Ompu Pulo Batu.

b. Guru Somaling

Guru Somalaing bermarga Pardede. Sebelum perang menjadi penasehat kesehatan lingkaran Sisingamangaraja. Pernah mendampingi Modigliani (peneliti Botani Italia) hingga terdorong mengungkapkan lahirnya ide Agama Malim ke hadapan Sisingamangaraja. Dibuang ke Banyuwangi, Pulau Jawa karena perlawanan kerasnya juga kepada Belanda).

c. Panglima Amandopang

Panglima Amandopang, juga disebut Mardopang Manullang, merupakan penasehat utama dari awal tahtanya Sisingamangaraja XII pada tahun 1450. Marga Sinambela dan Marga Manullang satu induk dengan Siraja Oloan.

d. Panglima Sarbut

Panglima Sarbut Tampubolon menyerang tangsi Belanda di Butar, sedang Belanda menyerbu Lintong dan berhadapan dengan Raja Ompu Babiat Situmorang. Tetapi, Sisingamangaraja XII menyerang juga ke Lintong Nihuta, Hutaraja, Sima-

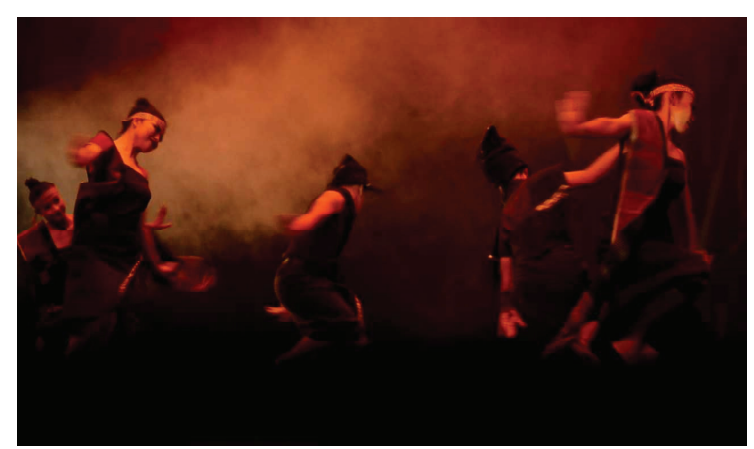

Gambar 4. Tortor Pembuka (mula-mula) Opera Batak Sisingamangaraja di Eksprimental Theatre University Malaya (Dokumen: Enrico Alamo, 2018)

ngarongsang, Huta Paung, Parsingguran, dan Pollung.

\section{e. Patuan Anggi}

Patuan Anggi, anak Sisingamangaraja dari salah satu istrinya, Boru Sagala. Ia selalu bersama Sutan Nagari untuk urusan penting dan rahasia sampai ke Aceh.

f. Boru Sagala

Istri Sisingamangaraja XII, di samping istri-istri lainnya, yakni Boru Simanjuntak, Boru Situmorang, Boru Nadeak, dan Boru Siregar. Ia turut meninggal dalam peperangan.

\section{g. Putri Lopian}

Putri Lopian berusia 17 tahun, adalah anak kesayangan Sisingamangaraja XII yang turut dalam peperangan. Hingga akhir hayatnya, ia mendampingi Sisingamangaraja XII berperang. Lopian ikut bergerilya mendampingi, dan ikut melakukan perlawanan.

h. Seseorang/Pencerita (Amalopas)

Ia adalah seorang yang mengabarkan berita. Alat musik hasapi yang selalu di tangannya menjadi ciri khas petualangan yang dilakukan. Pencerita selalu hadir di saat orang sedang membutuhkan, membawa kabar dan petuah baik maupun dalam keadaan bimbang. Ia menceritakan sosok pahlawan.

\section{Pembahasan Pertunjukan}

Perancangan rangkaian adegan dalam Opera Batak Sisingamangaraja XII episode Tongtang I Tano Batak dapat dijabarkan sebagai berikut. 


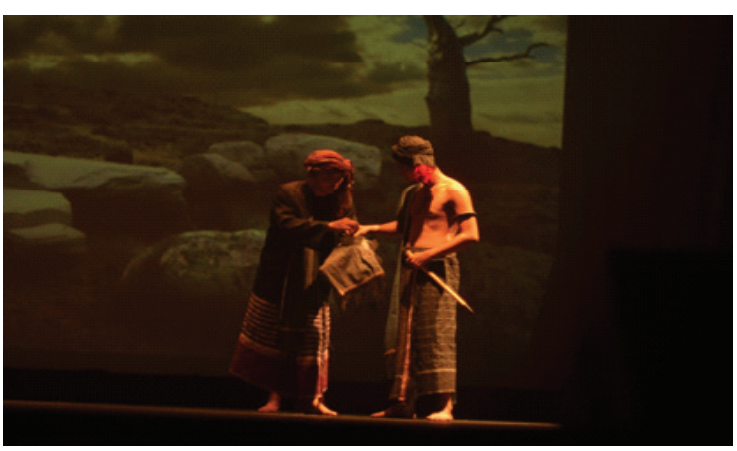

Gambar 5. Somalaing Pardede, Amandopang, dan Sisingamangaraja dalam adegan Opera Batak Sisingamangaraja di Eksprimental Theatre University Malaya (Dokumen: Enrico Alamo, 2018)

Bagian 1. Diawali oleh tortor pembuka. Contoh tarian seperti terlihat pada gambar 1 dan 2. Selanjutnya, muncul pencerita yang mengisahkan tentang sosok kepahlawanan dengan menggenakan ulos dan mendendangkan lagu Batak. Ia meliuk-liukkan badan dan bergerak-gerak ritmis sambil matanya mulai menyapu seisi ruangan dan mulailah ia berceloteh tentang sejarah dan pahlawannya. Sesekali ia menyindir penonton.

Bagian 2. Para prajurit menyusun gerakan sebagai persiapan perlawanan. Bagian ini disimbolkan melalui gerak tari dan video mapping. Pada gambar video mapping terlihat Lobu Tolu yang sudah dikuasai Pasukan Batak, kemudian berhasil dikuasai kembali oleh Belanda. Akhirnya, Sisingamangaraja XII dan pasukannya mundur ke Pasingguran. Sisingamangaraja XII bersikukuh melakukan perlawanan, namun guru Parmalim Somaling Pardede dan Panglima Amandopang Manulang memperingatkannya, seperti terlihat pada gambar 5.

Bagian 3. Para prajurit kembali berlatih dan mempersiapkan diri menyambut peperangan. Panglima Sorbut Tampubolon berbincang dengan Patuan Nagari. Mereka membicarakan tentang pengejaran pasukan Belanda dan posisi prajurit Batak yang kian terjepit.

Bagian 4. Boru Sagala sedang menasehati anak gadisnya Putri Lopian. Boru Sagala berusaha meredam keinginan Putri

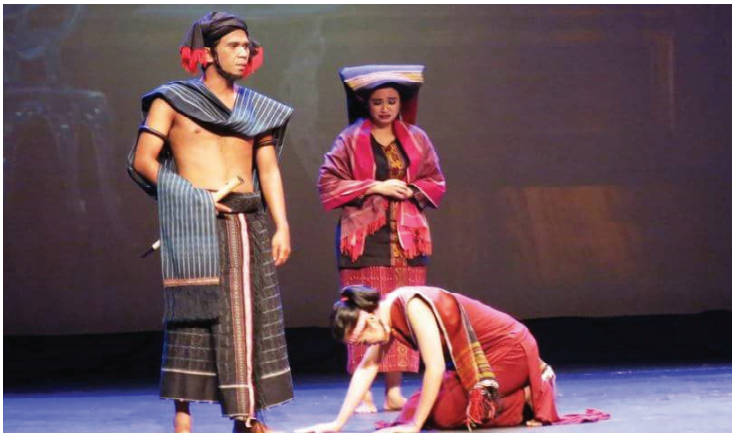

Gambar 6. Boru Sagala, Putri Lopian, dan Sisingamangaraja dalam adegan Opera Batak Sisingamangaraja di Eksprimental Theatre University Malaya (Dokumen: Enrico Alamo, 2018)

Lopian yang ingin berperang di garis depan. Tapi, keinginan Putri Lopian telah bulat. Ia ingin segera bergabung dengan para pejuang di medan peperangan. Sisingamangaraja yang mendengar hal ini semula keberatan dengan menasehatinya, namun kemudian mengizinkan Lopian untuk berperang. Contoh adegan terlihat pada gambar 6 .

Bagian 5. Pencerita muncul kembali memakai ulos sambil bersenandung sambil mengarahkan tongkatnya ke seluruh ruangan. Pencerita bertanya kepada seluruh hadirin tentang integritas, loyalitas, bahkan idealisme.

Bagian 6. Sisingamangaraja menuju sebuah tempat yang tinggi. Ia berdiri dan memandang semua rakyat yang ada di depannya. Ia mulai mengucapkan salam dengan bahasa Batak, lalu berbicara untuk membakar semangat semua parajuritnya. Para prajurit kembali terbakar semangat perjuangannya.

Bagian 7. Panglima Sarbut Tampubolon dan Panglima Amandopang Manulang membawa pasukannya menyisir hingga Dairi. Mereka berusaha bertahan dari kejaran Marsose.

Bagian 8. Prajurit Sisingamangaraja menyingkirke Kampung Pancinoran, di Lereng Gunung Batu Gaja, di Wilayah Dairi. Saat itu, Patuan Nagari memberitahu bahwa Patuan Anggi telah tewas. Ia juga melaporkan bahwa beberapa Panglima perang dan 
Permaisuri Boru Sagala telah tertangkap. Patuan Anggi menghadap Sisingamangaraja untuk mengabarkan hal ini.

Bagian 9. Pencerita kembali muncul dengan menggenakan ulos. Ia memainkan tongkatnya dan mulai berceloteh, sambil sesekali menatap nanar ke semua penonton. Pencerita menyampaikan isian atau kesimpulan dari seluruh cerita perjuangan sambil memberikan pesan kepada para hadirin. Musik penutup dimainkan.

\section{SIMPULAN}

Opera Batak merupakan kesenian tradisional masyarakat Batak Toba yang keberadaannya mulai terpinggirkan karena pegiat maupun penikmat kesenian ini lebih tergiur dengan kesenian modern. Tidak banyak muncul grup maupun komunitas yang menghidupkan kesenian Opera Batak ini. Sejak revitalisasi yang dimulai tahun 2002 kemudian dikembangkan pada tahun 2005 hingga 2015, pegiat Opera Batak bisa dihitung jari. Salah satunya, yang masih aktif adalah Thompson HS. Padahal, Opera Batak ini merupakan salah satu media seni (drama) untuk menyampaikan berbagai cerita, sejarah, mitos, legenda, dan cerita-cerita popular dalam kehidupan manusia. Sebut saja kisahkisah yang menjadi penuntun dalam kehidupan, seperti Si Boru Tumbaga, Sampuraga, Perempuan di Pinggir Danau, Mencari Si Jonaha, Srikandi Boru Lopian, dan banyak lagi.

Opera Batak Sisingamangaraja XII episode Tongtang I Tano Batak (Pertempuran di Tanah Batak) adalah lakon yang terinspirasi dari kisah kepahlawanan Sisingamangaraja XII yang digali melalui penelitian ke beberapa tempat, seperti Balige, Pematang Siantar, Sopo Surung, Bakara, Tarutung, dan lain sebagainya (Sumatera Utara). Karya Opera Batak Sisingamangaraja XII ini digarap dengan menggunakan konsep teater modern karena repertoar Opera Batak ini memiliki kesamaan pada pola maupun alur teater modern. Dari sisi keberadaannya, Opera Batak bisa juga dikatakan teater transisi. Yang membedakan antara teater modern dengan Opera Batak adalah pakem-pakem tradisi yang masih melekat dalam setiap pertunjukan Opera Batak. Setiap pertunjukan Opera Batak selalu digarap dengan musik dengan tortor sebagai pembuka dan penutup. Musik pengiring atau yang biasa disebut uninguningan, menggunakan instrumen tradisi, seperti hesek, garantung, hasapi, taganing dan suling. Untuk penokohannya, dijelaskan oleh amalopas (narator) yang juga sebagai penyampai pesan cerita Opera Batak, di samping tokoh-tokoh yang dibutuhkan.

Opera Batak Sisingamangaraja XII episode, Tongtang I Tano Batak (pertempuran Tanah Batak) merupakan sudut pandang yang lain dari sejarah yang ada. Cerita di dalamnya dibumbui oleh berbagai adegan kemanusiaan yang mengundang simpatik dan pesan, yang dianggap kontekstual dengan masa sekarang, yakni bahwa hidup ini fana, yang abadi adalah budi pekerti.

\section{Daftar Pustaka}

Anirun, S. (2002). Menjadi Sutradara. STSI Press: Bandung

Minawati, R. dan Nursyirwan. (2018). Kreativitas Garap sebagai Strategi Pengembangan Musik Kompang Grup Delima di Bantan Rua Bengkalis. Panggung, 28 (4): 346-359.

Purba, K. (2002). Opera Batak Tilhang Serindo: Pengikat Budaya Masyarakat Batak Toba di Jakarta. Yogyakarta: Kalika Bantul.

Putro, B. (1981). Karo dari Zaman ke Zaman. Medan: Yayasan Massa.

Pramutomo, R. M., Slamet MD, T. Mulyadi. (2018). Langen Carita Jaka Tingkir Opera Edukasi Anak. Panggung, 28 (4): 331-345.

Ruswandi, T. (2016). Kreativitas Mang Koko dalam Karawitan Sunda. Panggung, 26 (3): 92-107. 
Sangti, B. (1978). Sejarah Batak. Balige: Karl Sianipar.

Tambunan, A. P. (1977). Kamus Bahasa Batak Toba-Indonesia. Jakarta: Pusat Pembinaan Bahasa Departemen Pendidikan dan Kebudayaan.
Wikandia, R. (2016). Pelestarian dan Pengembangan Seni Ajang Sinar Pusaka pada Penyambutan Pengantin Khas Karawang. Panggung, 26 (3): 58-69. 